Актуальні проблеми розвитку економіки регіону. Вип 17. T.1

8. Voznyak, H. V. "Financial decentralization and sustainable endogenous growth of regions: formalization of areas of influence.” The world of finance, no.2(59), 2019, pp. 49-59.

9. Romer, P. M. "Growth based on increasing returns due to specialization." American Economic Review, vol. 77(2), 1987, p. 145.

10. Raytner, E. S. How rich countries became rich... And why poor countries remained poor. Summit book,2019.

11. Florida, R. Homo creatives. How a new class is conquering the world. Our format, 2018.

12. Florida, R. Creative class. People who change the future. Mann, Ivanov and Ferber, 2015.

13. Braczyk, H.-J., Cooke, P., and M. Heidenreich. Regional Innovation Systems: The Role of Governances in a Globalized World, 2nd ed. London, UCL Press, 1998.

14. Asheim, B. T., and L. Coenen. "Knowledge bases and regional innovation systems: Comparing Nordic clusters.” Research policy, vol. 8 (34), 2005, pp. 1173-1190.

15. Isaksen, A., Martin, R., and M. Trippl. "New avenues for regional innovation systems and policy." New avenues for regional innovation systems - Theoretical advances, empirical cases and policy lessons. Cham, Springer, 2018, pp. 1-19.

16. Isaksen, A., and M.Trippl. "Path development in different regional innovation systems: A conceptual analysis.” Innovation Drivers and Regional Innovation Strategies. New York, London, Routledge, 2016, pp. 78-80.

17. United Nations. Sustainable Development Goals 2016-2030, www.un.org.ua/ua/tsili-rozvytkutysiacholittia/tsili-staloho-rozvytku. 2016. Accessed 11 Jul. 2021

18. Machlup, F. Production and dissemination of knowledge in the United States. Moscow, Progress, 1966.

19. Toffler, E. Shock of the future. Trans. from English. Moscow, AST Publishing House, 2003.

20. Toffler, E. The third wave. Trans. from English. Moscow, AST Publishing House, 2004.

21. Toffler, E. Metamorphoses of power. Moscow, AST Publishing House, 2002.

22. Stepanenko, V. P. "Information society." Encyclopedia of Modern Ukraine: electronic version. Kyiv, Institute of Encyclopedic Research of the National Academy of Sciences of Ukraine, 2006, esu.com.ua/search_articles.php?id=12462. Accessed 05 Jul. 2021.

23. Buchanan, J. M. “An Economic Theory of Clubs.” Economica, Feb 1965, 32 (125), pp. 1-14.

24. Amosha, O. I. (Ed.), Cherevatskyy, D. Yu., et al. Circular smart specialization of old industrial mining regions of Ukraine. Kyiv, Institute of Industrial Economics, National Academy of Sciences of Ukraine, 2020, pp. 158-159.

25. Olson, M. The logic of collective action: public goods and group theory. Kyiv, Libra, 2004.

26. Tapscott, D., and Williams, E. Wikinomics. How Mass Collaboration Changes Everything. Moscow, Best Business Books, 2009.

УДК 352.071:005.21(477)

doi: 10.15330/apred.1.17.162-173

\title{
СУТНІСТЬ СТРАТЕГІЇ СОЦАЛЬНО-ЕКОНОМІЧНОГО РОЗВИТКУ ОТГ В КОНТЕКСТІ ЗМІНИ ПІДХОДІВ ДО РЕГІОНАЛЬНОГО РОЗВИТКУ В УКРАЇ̈I
}

1 ДВНЗ «Прикарпатський національний університет імені

Василя Стефаника»,

Міністерство освіти і науки України,

кафедра теоретичної і прикладної економіки,

вул. Шевченка, 57, м. Івано-Франківськ,

76018, Україна,

тел.: 0990630085,

e-mail: styartsave959@gmail.com,

ORCID: 0000-0003-4802-037X 
Анотація. Стаття спрямована на дослідження сутності стратегії соціально-економічного розвитку ОТГ в контексті зміни підходів до регіонального розвитку в Україні. Актуалізація необхідності у дослідженні й розробці стратегії соціально-економічного розвитку ОТГ зумовлена, передусім, створенням територіальних громад та процесами децентралізації, тобто отриманням більших повноважень стосовно розподілу і використання ресурсів громади. 3 метою проведення дослідження стосовно стану зацікавленості населення до такої тематики, здійснено аналітичні процедури із застосуванням Google Trends, який дає змогу ідентифікувати популярність запитів та існуючих трендів.

В результаті здійсненого графічного аналізу трендів установлено, що значення запитів за словом «Стратегія» за останні 2 роки має стабільну динаміку. Терміни «Стратегія ОТГ» та «Стратегія розвитку ОТГ» мають поодиноке одиничне значення пошукових запитів, а терміни «Стратегія громади», «Стратегія соціально-економічного розвитку ОТГ» мають нульову динаміку пошуку. Така ситуація вказує на те, що зараз ОТГ перебувають на початковій стадії свого становлення і розвитку, а тому їхні представники ще не у повній мірі оволоділи необхідними інструментами ефективного управління ОТГ.

Встановлено, що дослідження стратегії ОТГ носять одиничний характер і у міру наявності кардинальних відмінностей від функціонування підприємств, не можуть застосовуватися для формування стратегії соціально-економічного розвитку ОТГ. Тому запропоновано авторське бачення трактування терміну «стратегія ОТГ» : це довгостроковий план (програма) розвитку територіальної громади, що передбачає визначення генерального напряму (курсу, орієнтиру) розвитку територіальної громади та сукупність послідовних дій для забезпечення іії конкурентоспроможності та інвестиційної привабливості.

Визначено, що стратегія соціально-економічного розвитку ОТГ в контексті зміни підходів до регіонального розвитку в Україні: забезпечує сумісність усіх планів розвитку територіальної громади; узгоджує всі складові соціально-економічного розвитку територіальної громади, об'єднуючи їх у єдине ціле; є інструментом для планування, реалізації та контролю генерального орієнтиру соціально-економічного розвитку територіальної громади; $є$ засобом досягнення запланованого результату; $\epsilon$ засобом для розв'язання ключових проблем в територіальній громаді.

Ключові слова: стратегія, соціально-економічний розвиток, об'єднані територіальні громади, ОТГ, громада, регіональний розвиток, децентралізація.

\title{
Sologub S.I. ESSENCE OF UTC SOCIO-ECONOMIC DEVELOPMENT STRATEGY IN THE CONTEXT OF CHANGING APPROACHES TO REGIONAL DEVELOPMENT IN UKRAINE
}

\author{
${ }^{1}$ Vasyl Stefanyk Precarpathian National University, \\ Ministry of Education and Science of Ukraine, \\ Department of Theoretical and Applied Economics, \\ Shevchenko str., 57, Ivano-Frankivsk, \\ 76018, Ukraine, \\ tel.: 0990630085, \\ e-mail: styartsave959@gmail.com, \\ ORCID: 0000-0003-4802-037X
}

\begin{abstract}
The article is aimed at studying the essence of the strategy of socio-economic development of UTC in the context of changing approaches to regional development in Ukraine. The actualization of the need for research and development of a strategy for socio-economic development of UTC is due primarily to the creation of territorial communities and decentralization processes, gaining more power over the allocation and use of community resources. In order to conduct a study on the state of interest of the population in this topic, analytical procedures were performed using Google Trends, which allows identifying the popularity of queries and existing trends.
\end{abstract}


As a result of the conducted graphic analysis of trends, it is established that the value of queries for the word «Strategy» for the last 2 years has stable dynamics. The terms «UTC Strategy» and «UTC Development Strategy» have a single unit meaning of search queries, and the terms «Community Strategy», «UTC Socio-Economic Development Strategy» have zero search dynamics. This situation indicates that UTCs are now in the early stages of their formation and development, and therefore their representatives have not yet fully mastered the necessary tools for effective UTC management.

It is established that the studies of UTC strategy are isolated and, in the presence of radical differences from the functioning of enterprises, cannot be used to form a strategy of socio-economic development of UTC. Therefore, the author's vision of the interpretation of the term «UTC strategy» is proposed: it is a long-term plan (program) of territorial community development, which provides a general direction (course, landmark) of territorial community development and a set of consistent actions to ensure its competitiveness and investment attractiveness.

It is determined that the strategy of socio-economic development of UTC in the context of changing approaches to regional development in Ukraine: ensures the compatibility of all development plans of the territorial community; coordinates all components of socio-economic development of the territorial community, uniting them into a single whole; is a tool for planning, implementation and control of the general guideline of socio-economic development of the territorial community; is a means to achieve the planned result; is a tool for solving key problems in the local community.

Key words: strategy, socio-economic development, united territorial communities, UTC, community, regional development, decentralization.

Вступ. На сучасному етапі соціально-економічного розвитку України особливу роль відіграють процеси децентралізації влади, які розпочались у 2014 р. і на сьогоднішній день активно імплементуються через надання ширших повноважень органам місцевого самоврядування у межах новостворених об'єднаних територіальних громад (ОТГ). Така ситуація зумовлює необхідність у формуванні теоретикометодичних основ забезпечення соціально-економічного розвитку громад, у основному, через зростання рівня відповідальності місцевої влади перед громадами за розподіл й ефективне використання ресурсів, вирішення соціальних проблем громади, обгрунтування вибору відповідного шляху розвитку ОТГ.

Наведенні факти сприяють застосуванню сучасного, більш ефективного інструментарію управління новоствореними об'єднаними територіальними громадами, що становить новітню парадигму управління у контексті сталого розвитку. Слід відмітити, що важливим пріоритетним видом діяльності, на котрий потрібно звертати особливий акцент є розробка стратегії соціально-економічного розвитку ОТГ.

Доцільно зазначити, що проблеми впровадження в практичну діяльність територіальних громад сучасних концепцій, інструментів й технологій, зокрема стратегічних, що забезпечують їх результативність і ефективність, наводяться в наукових публікаціях таких дослідників, як: В. Бабаєв, В. Бакуменко, О. Бобровська, С. Бородін, С. Бушуєв, Т. Безверхнюк, О. Бойко-Бойчук, В. Вакуленко, О. Васильєва, П. Ворон, Н. Гончарук, А. Гошко, В. Дзюндзюк, Г. Дмитренка, В. Кравченко, В. Куйбіда, П. Надолішній, В. Пархоменко, В. Прошко, М. Пухтинський, І. Розпутенко, В. Рубцов, С. Саханенко, С. Серьогін, О. Тертишня, В. Толкованов, А. Чемерис та ін. Однак, $з$ урахуванням наукових напрацювань із обраної тематики, все ще є велика кількість проблемних точок, котрі потребують подальшого дослідження.

Постановка завдання. Актуалізація необхідності у дослідженні й розробці стратегії соціально-економічного розвитку ОТГ зумовлена, передусім, створенням територіальних громад та процесами децентралізації, тобто отриманням більших повноважень стосовно розподілу і використання ресурсів громади. А тому виникає потреба у дослідженні сутності стратегії соціально-економічного розвитку ОТГ в контексті зміни підходів до регіонального розвитку в Україні. 
Результати. 3 метою проведення дослідження стосовно стану зацікавленості населення до такої тематики, здійснено аналітичні процедури із застосуванням Google Trends, що являє собою «публічний web-додаток корпорації Google, заснований на пошуку Google, який показує, як часто певний термін шукають по відношенню до загального обсягу пошукових запитів у різних регіонах світу і на різних мовах; це інструмент для аналізу популярності і сезонності пошукових запитів» [1]. На основі застосування такого інструментарію можливо: ідентифікувати популярність запитів та існуючих трендів; здійснити їх оцінку; проаналізувати взаємозв'язок між географічними даними та популярністю відповідних запитів у пошуковій системі чи тем у загальному.

Особливістю такого аналізу є те, що цифри показують популярність пошукового терміна відносно найвищої точки на графіку для певного регіону та періоду часу. 100 це пік популярності терміна. 50 означає, що популярність терміна вдвічі менша. 0 означає, що було замало даних про цей термін [1].

Для здійснення діагностики досліджуваної тематики взято такі терміни: «Стратегія», «Стратегія ОТГ», «Стратегія розвитку ОТГ», «Стратегія соціальноекономічного розвитку ОТГ», «Стратегія громади», «ОТГ», «громада». 3 метою одержання інформації, яка б відповідала принципам повноти та аналітичності, обрано досліджуваний період - останні 5 років, у межах котрих проводилися запити у пошуковій системі Google у розрізі областей України (рис. 1). Слід відмітити, що на горизонтальній вісі діаграми наведено термін, протягом котрого здійснене дослідження, а на вертикальній - як за часто здійснювався пошук обраного терміну у співставленні із загальним числом запитів у пошуковій системі Google. Тобто, 3 допомогою такого представлення можна побачити сформований тренд пошукового запиту.

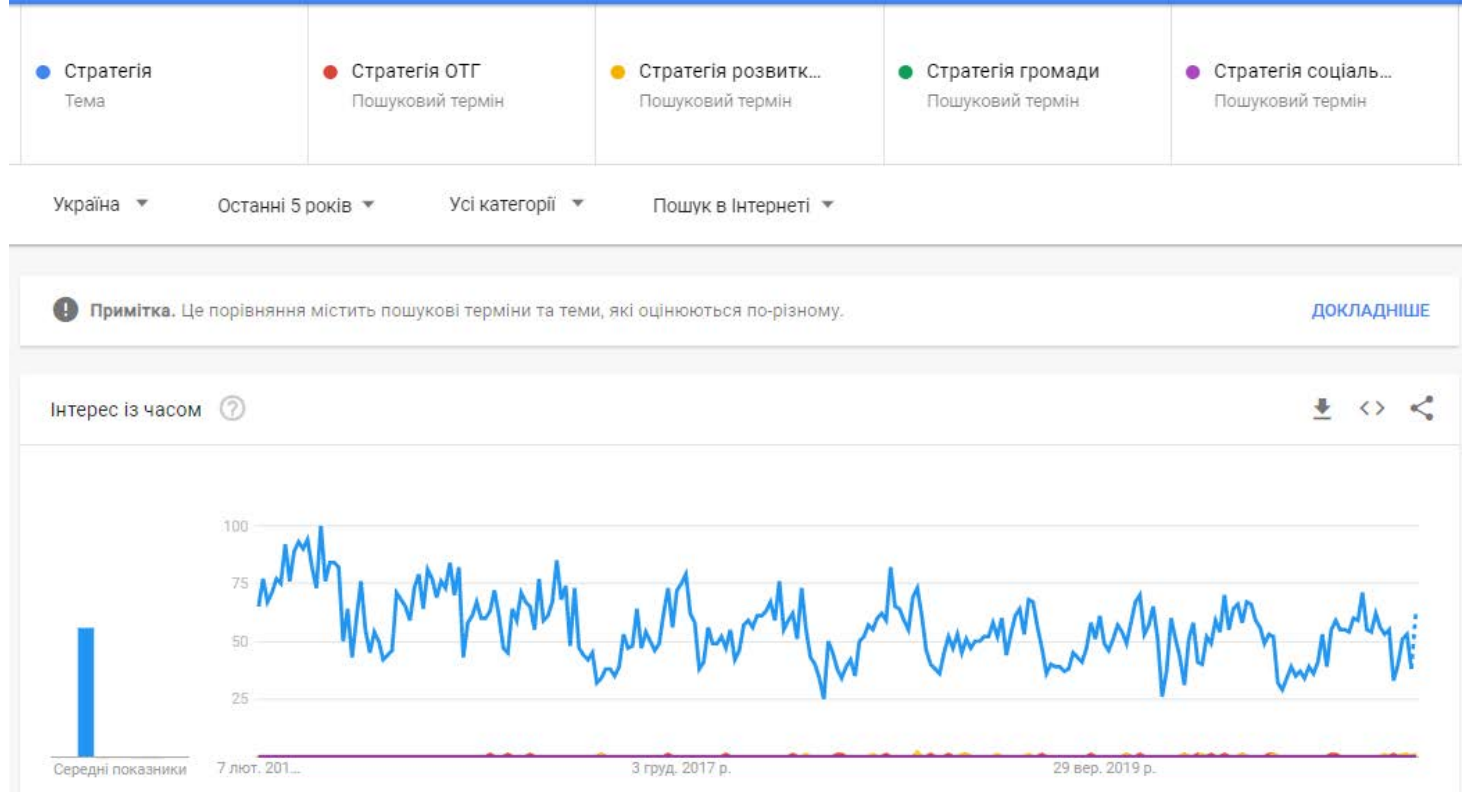

Puc. 1. Тренди пошукових запитів в Google за термінами «Стратегія», «Стратегія ОТГ», «Стратегія розвитку ОТГ», «Стратегія громади», «Стратегія соціальноекономічного розвитку ОТГ» за останні 5 років

Fig. 1. Google search query trends in terms of «Strategy», "UTC Strategy», «UTC Development Strategy», «Community Strategy», «UTC Socio-Economic Development

Strategy» for the last 5 years

Джерело: отримано автором із Google Тренди [1]. 
Актуальні проблеми розвитку економіки регіону. Вип 17. T.1

В результаті здійсненого графічного аналізу трендів установлено, що середнє значення запитів за словом «Стратегія» становить 56, і хоча у порівнянні із 2016 р. загальний тренд дещо знизився, проте за останні 2 роки він має стабільну динаміку. Терміни «Стратегія ОТГ» та «Стратегія розвитку ОТГ» мають поодиноке одиничне значення пошукових запитів, а терміни «Стратегія громади», «Стратегія соціальноекономічного розвитку ОТГ» мають нульову динаміку пошуку. Така ситуація вказує на те, що зараз ОТГ перебувають на початковій стадії свого становлення і розвитку, а тому їхні представники ще не у повній мірі оволоділи необхідними інструментами ефективного управління ОТГ. Про це засвідчує наступний проведений аналіз трендів пошукових запитів в Google, за словами «Стратегія», «ОТГ», «Громада» за останні 5 років (рис. 2).

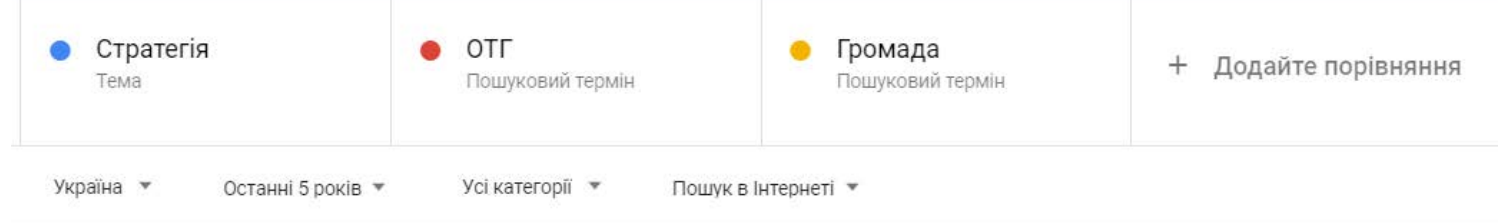

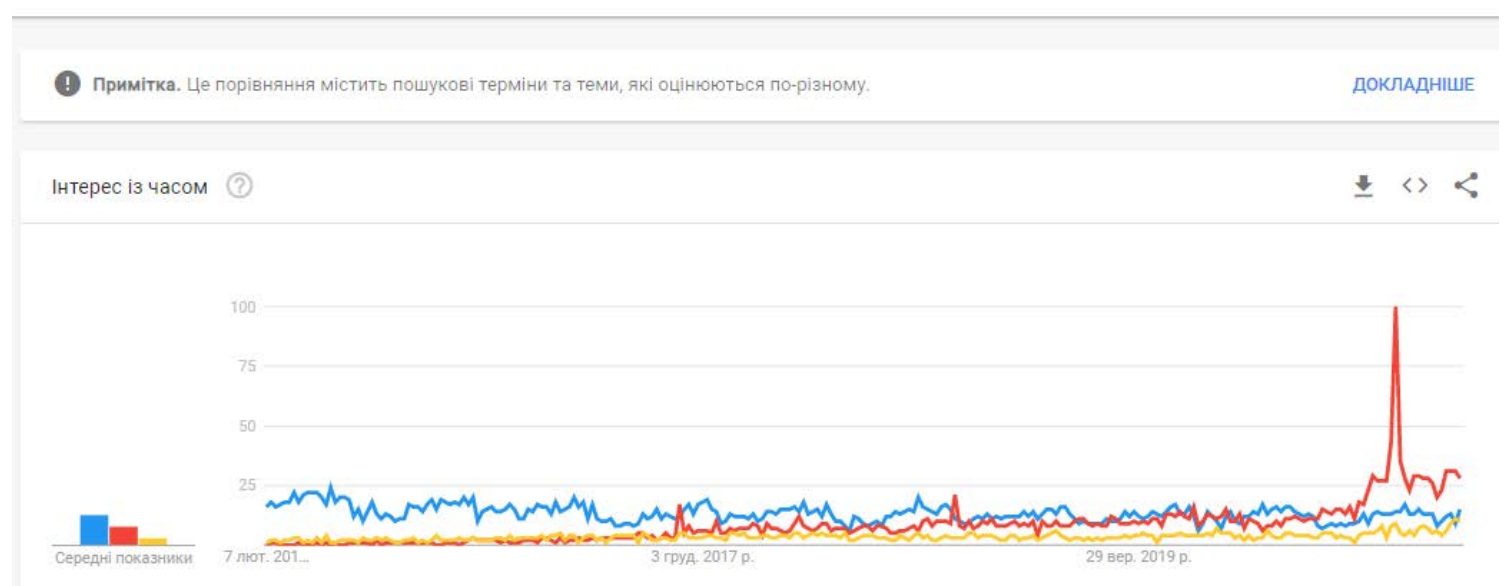

Puc. 2. Тренди пошукових запитів в Google за термінами «Стратегія», «ОТГ», «Громада» за останні 5 років

Fig. 2. Trends of Google search queries in terms of «Strategy», «UTC», «Community» for the last 5 years

Джерело: отримано автором із Google Тренди [1].

У цілому спостерігаючи за такими трендами впродовж останніх 5 років, можна відмітити зростання зацікавленості до терміну «ОТГ» та незначне зростання до терміну «громада». Термін «стратегія» впродовж останніх 5 років має стабільний тренд у пошуковій системі і усередньому становить 13.

Прорив у пошукових запитах спостерігався у останній тиждень жовтня 2020 р. (25-31.10.2020 р.): із коефіцієнтом у 100 запитів припадає на ОТГ, у той час, коли на стратегію - 14, а на громаду - 9. Така ситуація пов'язана із проведенням місцевих виборів до територіальних громад. Про це, також, засвідчує проведений аналіз за «схожими запитами» (рис. 3), тобто коли користувачі, які шукали відповідний термін, також вводили схожі запити. Так, у п’ятірку схожих запитів війшли такі терміни, як: «вибори 2020», «вибори в ОТГ», «ОТГ це», «ЦВК», «Олевська ОТГ». 


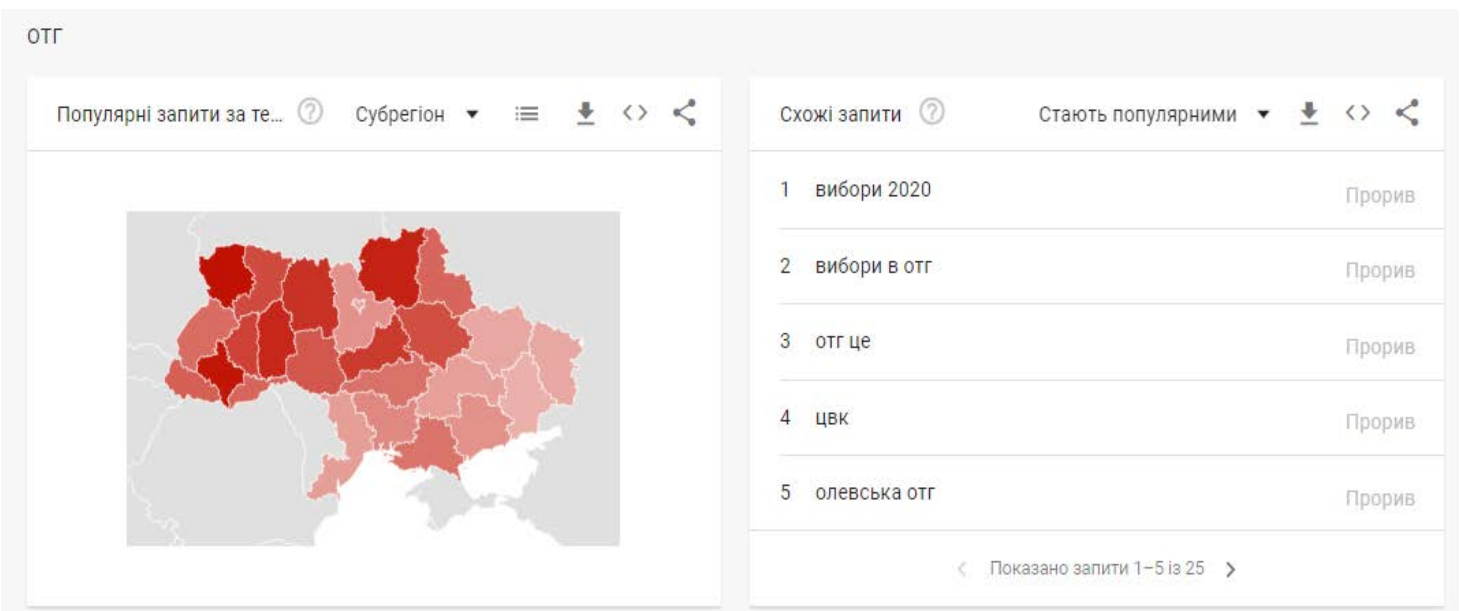

Puc. 3. Популярність запиту «ОТГ» за регіонами України та схожі запити

Fig. 3. The popularity of the query «UTC» by regions of Ukraine and similar queries Джерело: отримано автором із Google Тренди [1].

Графічний аналіз за популярними запитами у розрізі територіальних одиниць дає змогу дізнатися, де саме досліджуваний термін був найпопулярніший протягом вибраного періоду часу. Значення коливаються від 0 до 100. 100 - це місце з найвищою популярністю відносно загальної кількості пошуків, 50 - це місце, де термін шукали вдвічі рідше, а 0 - це місце, де було замало даних про цей термін. Із рис. 3 видно, що термін «ОТГ» $є$ найбільш популярним у Волинській області - 100, Івано-Франківській області - 98, Чернігівській області - 92. Найменш популярним у Донецькій - 11, Луганській - 16, Харківській - 16. Така ситуація може вказувати на громадську активність мешканців таких областей та їхню національну самосвідомість.

Проведений аналіз порівняльного розподілу термінів за регіонами України дав змогу встановити, що найбільш популярними 3-поміж слів «Стартегія», «ОТГ», «Громада» є слово «Стратегія» у м. Севастополі та у цілому у Криму, а от на іншій території України простежується зростання зацікавленості до слів «ОТГ» та «Громада». Так, у м. Києві припадає 74 \% від трьох досліджуваних пошукових слів припадає на термін «Стратегія», $16 \%$ на «ОТГ», і 10\% на «Громада» (рис. 4). Схожа ситуація і у Харківській та Донецькій областях (68\%, 21\%, 11\% та 68\%, 19\%, 13\% відповідно). В інших областях відсоток запитів коливається у межах 25-63\%.

Слід відмітити, що термін «ОТГ» найбільш популярний у Івано-Франківській області - 65\%, у Чернігівській області - 61\% та у Волинській області - 59\% від досліджуваних термінів, а в інших областях відсоток запитів коливається у межах 16$56 \%$.

Термін «Громада» найбільш популярний у Запорізькій області - 26\%, Тернопільській області - 26\% та Київській області - 20\%, а в інших областях відсоток запитів коливається у межах 10-18\%.

У результаті проведеного графічного аналізу, вважаємо за необхідне сдійснити дослідження сутності терміну «стратегія», оскільки саме цей термін має найбільший попит у системі пошукових запитів, а потім дослідити термін «стратегія ОТГ» та «стратегія соціально-економічного розвитку ОТГ». 


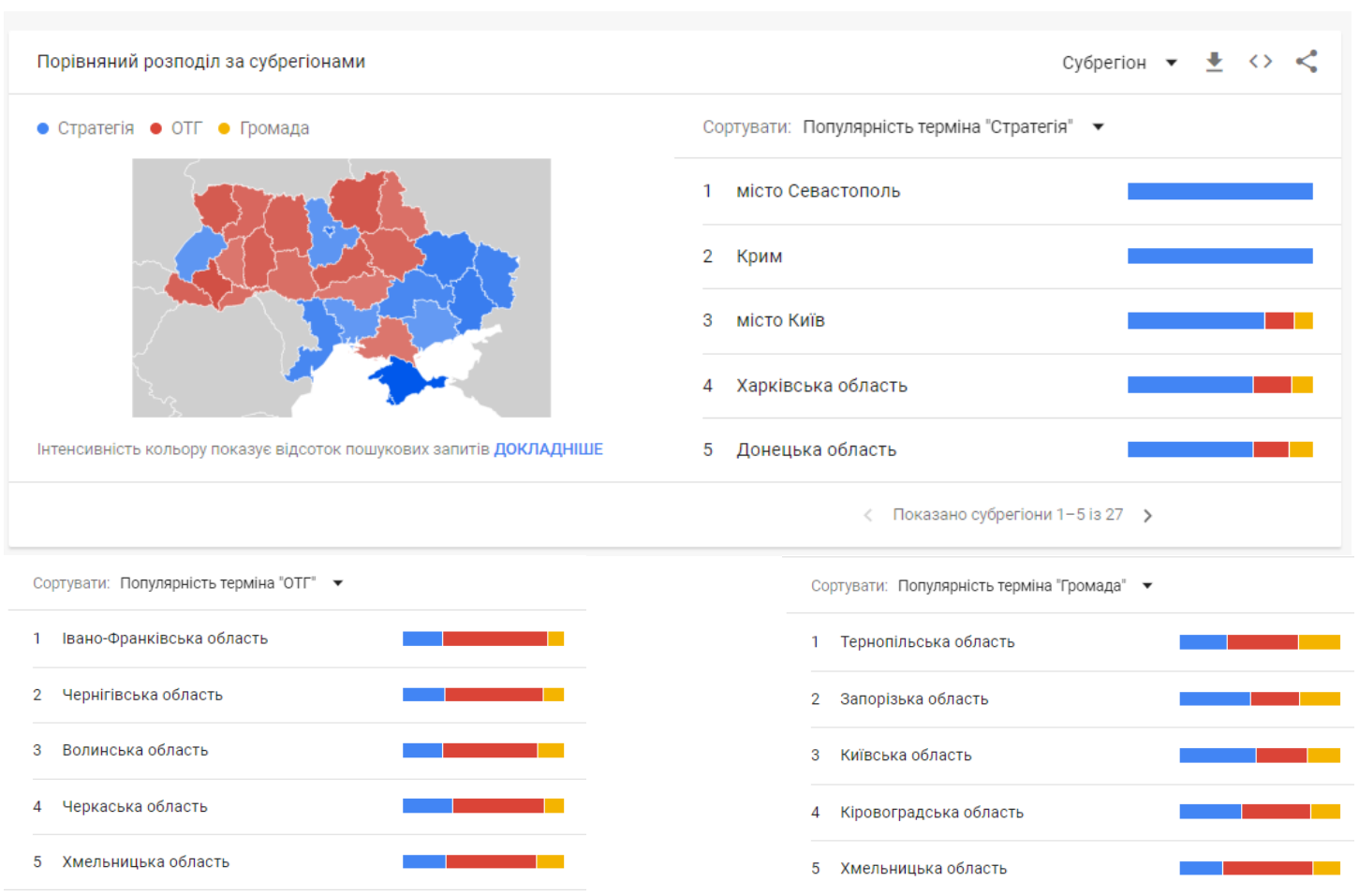

Puc. 4. Порівняльний розподіл пошукових запитів за термінами «Стартегія», «ОТГ», «Громада» у розрізі регіонів України

Fig. 4. Comparative distribution of search queries in terms of «Strategy», «UTC», «Community» in terms of regions of Ukraine

Джерело: отримано автором із Google Тренди [1].

Питанню вивчення теоретико-практичних аспектів трактування терміну «стратегія» присвятили свої наукові праці вітчизняні й зарубіжні вчені: І. Ансофф [2], О. Віханський [3], А. Гершун, М. Горський [4], В. Глюк [5], Г. Гольдштейн [6], Дж. Джонсон, К. Скулс [7], П. Дойль [8], В. Сфремов [9], Б. Карлофф [10], М. Крук [11], В. Маркова, С. Кузнєцова [12], М. Мескон, М. Альберт, Ф. Хедоурі [13], Г. Мінсберг [14], В. Пономаренко, О. Пушкар, О. Тридід [15], М. Портер [16], А. Томпсон, А. Стрікленд, [17], Н. Туленков [18], Л. Федулова, О. Захарова [19], А. Чендлер [20].

Саме слово «стратегія» має давньогрецьке походження («stratos» перекладається як «армія», а «agos» означає «я керую»). 3 урахуванням цього, термін «стратегія» у первинному своєму значенні трактується як мистецтво чи наука ведення військових дій, а деколи трапляється переклад як «мистецтво керівництва суспільною, політичною боротьбою» [21].

В теперішньому трактуванні стратегія має: мати чіткі цілі; підтримувати громадську ініціативу; зосереджувати основні зусилля у потрібний момент часу та у визначеному місці; сприяти використанню мінімальних доступних ресурсів з метою отримання максимально-можливого результату; ідентифікувати управлінську ланку.

Таким чином, можна констатувати, що поняття стратегії соціально-економічного розвитку громад $є$ багатогранним та багатоаспектним [21].

Трактування терміну «стратегія» вітчизняними й зарубіжними науковцями систематизовано і наведено у табл. 1. 
Трактування терміну «стратегія» науковцями

Interpretation of the term «strategy» by scientists

\begin{tabular}{|c|c|c|}
\hline $\begin{array}{l}\text { № } \\
\text { ПI/II }\end{array}$ & Автор & Визначення \\
\hline 1 & 2 & 3 \\
\hline 1. & I. Ансофф [2, с. 68] & $\begin{array}{l}\text { Стратегія - це набір правил для прийняття рішень, } \\
\text { якими організація керується у своїй діяльності }\end{array}$ \\
\hline 2. & О. Віханський $[3$, с. 88] & $\begin{array}{l}\text { Стратегія - це довгостроковий, якісно новий } \\
\text { визначений напрям розвитку, що стосується сфери, } \\
\text { засобів і форм діяльності, системи відносин, а також } \\
\text { позицій у зовнішньому середовищі, що обумовлює } \\
\text { виконання поставлених цілей }\end{array}$ \\
\hline 3. & $\begin{array}{c}\text { А. Гершун, } \\
\text { М. Горський }[4, \text { с. 19] }\end{array}$ & $\begin{array}{l}\text { Стратегія - це шлях, що складається з декількох етапів } \\
\text { від теперішнього стану до цільового стану, що } \\
\text { планується. План, що інтегрує в єдине ціле такі } \\
\text { елементи: головні цілі, політику, цінності, філософію, } \\
\text { ідеологію, дії }\end{array}$ \\
\hline 4. & В. Глюк $[5$, с. 685$]$ & $\begin{array}{l}\text { Стратегія - це уніфікований, інтегрований і зрозумілий } \\
\text { план, розроблений таким чином, щоб бути впевненим у } \\
\text { досягненні цілей підприємства }\end{array}$ \\
\hline 5. & $\begin{array}{l}\text { Г. Гольдштейн }[6, \text { c. } \\
183]\end{array}$ & $\begin{array}{l}\text { Стратегія - це система дій і управлінських підходів, } \\
\text { які використовуються для досягнення організаційних } \\
\text { завдань і цілей організації }\end{array}$ \\
\hline 6. & $\begin{array}{c}\text { Дж. Джонсон та К. } \\
\text { Скулс } \\
{[7]}\end{array}$ & $\begin{array}{l}\text { Стратегія - це напрям і масштаб дій у довгостроковому } \\
\text { плані, що в ідеалі приводить ресурси компанії у } \\
\text { відповідність до дінливого } \\
\text { функціонування (ринки, споживачі і клієнти) таким } \\
\text { чином, щоб компанія відповідала очікуванням } \\
\text { власників часток участі в ній }\end{array}$ \\
\hline 7. & П. Дойль [8, с. 36] & $\begin{array}{l}\text { Стратегія - це комплекс прийнятих рішень } \\
\text { розміщення ресурсів і досягнення довгострокових } \\
\text { конкурентних переваг на цільових ринках }\end{array}$ \\
\hline 8. & В. С. Сфремов [9, с. 89] & $\begin{array}{l}\text { Стратегія - це образ дій, що обумовлює цілком } \\
\text { визначену i відносно стійку лінію поведінки на } \\
\text { довготривалому інтервалі часу }\end{array}$ \\
\hline 9. & Б. Карлофф [10, с. 148] & $\begin{array}{l}\text { Стратегія - це узагальнююча модель дій, необхідних } \\
\text { для досягнення встановлених цілей шляхом } \\
\text { координації і розподілу ресурсів компанії }\end{array}$ \\
\hline 10. & М. Д. Крук [11, с. 113] & $\begin{array}{l}\text { Стратегія - це правила прийняття рішень, які } \\
\text { формуються в момент початку їх реалізації }\end{array}$ \\
\hline 11. & $\begin{array}{l}\text { В. Д. Маркова, С. А. } \\
\text { Кузнецова }[12, \text { с. } 178]\end{array}$ & $\begin{array}{l}\text { Стратегія - це програма дій, що формує пріоритети } \\
\text { проблем і ресурси для досягнення основних цілей }\end{array}$ \\
\hline
\end{tabular}


Продовження табл.1

\begin{tabular}{|c|c|c|}
\hline 12. & $\begin{array}{c}\text { М. Х. Мескон, М. } \\
\text { Альберт, } \\
\text { Ф. Хедоурі [13, с. 231] }\end{array}$ & $\begin{array}{l}\text { Стратегія - це детальний усесторонній комплексний } \\
\text { план, призначений для забезпечення та досягнення місї } \\
\text { і досягнення цілей підприємства }\end{array}$ \\
\hline 13. & Г. Мінсберг [14, с. 472] & $\begin{array}{l}\text { Стратегія - це єдність 5-ти елементів: план, приклад, } \\
\text { позиціонування, перспектива і дія, тобто певний набір } \\
\text { курсів дій, сформованих згідно із ситуацією }\end{array}$ \\
\hline 14. & $\begin{array}{l}\text { В. С. Пономаренко, О. } \\
\text { І. Пушкар, } \\
\text { О. М. Тридід [15, с. } \\
\text { 549] }\end{array}$ & $\begin{array}{l}\text { Стратегія - це ділова концепція розвитку підприємства } \\
\text { на визначену стратегічну перспективу, що } \\
\text { представлена у вигляді довгострокової програми } \\
\text { конкретних дій, здатних реалізувати цю концепцію та } \\
\text { забезпечити конкурентні переваги в досягненні цілей }\end{array}$ \\
\hline 15. & М. Портер [16, с. 128] & $\begin{array}{l}\text { Стратегія - це аналіз внутрішніх процесів та взаємодій } \\
\text { між різними складовими організації, позиціонування } \\
\text { організації щодо галузевого середовища }\end{array}$ \\
\hline 16. & $\begin{array}{l}\text { А. А. Томпсон, А. Дж. } \\
\text { Стрікленд, } \\
{[17, \text { с. } 11]}\end{array}$ & $\begin{array}{l}\text { Стратегія - це план управління підприємством, } \\
\text { спрямований на зміцнення його позицій, задоволення } \\
\text { потреб споживачів і досягнення поставлених цілей }\end{array}$ \\
\hline 17. & Н. Туленков [18, с. 106] & $\begin{array}{l}\text { Стратегія - це встановлена на досить тривалий період } \\
\text { сукупність норм, орієнтирів, напрямків, сфер, способів } \\
\text { i правил діяльності, що забезпечують зростання і } \\
\text { високу конкурентоспроможність організації, які } \\
\text { зміцнюють позиції на ринку, підвищують здатність до } \\
\text { виживання в умовах конкуренції }\end{array}$ \\
\hline 18. & $\begin{array}{c}\text { Л. І. Федулова, О. В. } \\
\text { Захарова }[19, \text { с. } 43]\end{array}$ & $\begin{array}{l}\text { Стратегія - це таке поєднання (відповідність) ресурсів і } \\
\text { навичок організації, } 3 \text { одного боку, і можливостей, } \\
\text { ризику, що виходять } 3 \text { навколишнього середовища, } 3 \\
\text { іншого боку, діючи в дійсному і майбутньому, при } \\
\text { якому організація сподівається досягнути своєї } \\
\text { основної мети }\end{array}$ \\
\hline 19. & А. Чандлер [20, с. 129] & $\begin{array}{l}\text { Стратегія - це визначення основних довгострокових } \\
\text { цілей та завдань, затвердження курсу дії, ресурсів, які } \\
\text { необхідні для досягнення цілей }\end{array}$ \\
\hline
\end{tabular}

Джерело: складено автором.

Вивчення спеціальної літератури, дало змогу встановити, що дослідники виокремлюють кілька підходів до трактування терміну «стратегія»:

1. Класичний підхід - передбачає, що під стратегією слід розуміти засіб успішного досягнення поставлених цілей підприємств. Таку точку зору підтримують наступні науковці: В. Глюк [5], Г. Гольдштейн [6], Б. Карлофф [10], В. Д. Маркова, С. А. Кузнецова [12], А. Чандлер [20] та ін. Зазначений підхід базується на позиції авторів, що встановлення цілей підприємств взаємопов'язане із визначенням шляхів їх досягнення і тому в цьому розумінні стратегія ідентифікується як план чи модель дій.

2. Концептуальний підхід - передбачає, що під стратегією слід розуміти набір правил прийняття рішень. До науковців, які підтримують таку позицію відносяться: Г. Мінцберг [14], I. Ансофф [2], М. Портер [16] та ін. Особливістю такого підходу є те, що автори роблять акцент на всеосяжний характер стратегії, так як відповідний набір 
правил передбачає вирішення проблемних питань розвитку підприємств, iз урахуванням чинників зовнішнього та внутрішнього середовища.

3. Комплексний підхід включає у себе розуміння стратегії як засобу досягнення цілей й програми функціонування підприємств у взаємозв'язку із зовнішнім середовищем (тобто взаємодія із конкурентами, клієнтами, акціонерами тощо). Науковцями, які підтримують таку точку зору є: Дж. Джонсон, К. Скулс [7], М. Туленков [18] та ін. Підсумовуючи можемо відмітити, що за такого підходу стратегія має багатофункціональний характер.

Проведена емпірична оцінка терміну «стратегія» у частині трактування його різними дослідниками, дала змогу встановити, що існуючі різноманітні авторські погляди свідчать про багатоаспектність й складність терміну «стратегія».

У результаті вивчення спеціальної наукової літератури, також встановлено, що основні теоретико-методичні дослідження щодо стратегії стосуються підприємств і враховують їхню специфіку функціонування. А дослідження стратегії ОТГ носять одиничний характер і у міру наявності кардинальних відмінностей від функціонування підприємств, не можуть застосовуватися для формування стратегії соціальноекономічного розвитку ОТГ.

3 огляду на таку ситуацію, запропоновано авторське бачення трактування терміну «стратегія ОТГ»: це довгостроковий план (програма) розвитку територіальної громади, що передбачає визначення генерального напряму (курсу, орієнтиру) розвитку територіальної громади та сукупність послідовних дій для забезпечення іiі конкурентоспроможності та інвестиційної привабливості.

Мова йде про відповідний набір норм, орієнтирів, напрямків, сфер, правил, що мають сприяти забезпеченню успішному досягненню головних довготермінових цілей громади для розв'язання ключових iï проблем. Така стратегія має відображати концепцію розвитку територіальної громади у довготерміновій перспективі для забезпечення конкурентоспроможності та інвестиційної привабливості громади, забезпечувати сумісність усіх планів розвитку громади, завчасно реагувати на зміни у зовнішньому та внутрішньому середовищі. Таке трактування дасть змогу закласти фундаментальні теоретико-методичні основи у досліджуваній проблематиці та стати рушійним фактором для проведення наступних досліджень.

У той час хочемо відмітити, що важливим $\epsilon$ також застосування терміну «стратегія соціально-економічного розвитку ОТГ», оскільки термін «стратегія ОТГ» носить узагальнюючий характер і не відображає відповідність цілям сталого розвитку. Тому під стратегією соціально-економічного розвитку ОТГ пропонуємо розуміти довгостроковий план (програму) розвитку територіальної громади, що має на меті забезпечення економічного розвитку та розв'язання її соціальних проблем з допомогою визначення послідовних дій у контексті реалізації цілей сталого розвитку.

Отже, 3 урахуванням вищенаведеного можна констатувати, що стратегія соціально-економічного розвитку ОТГ в контексті зміни підходів до регіонального розвитку в Україні відіграє таку роль:

- забезпечує сумісність усіх планів розвитку територіальної громади;

- узгоджує всі складові соціально-економічного розвитку територіальної громади, об'єднуючи їх у єдине ціле;

- $є$ інструментом для планування, реалізації та контролю генерального орієнтиру соціально-економічного розвитку територіальної громади;

- є засобом досягнення запланованого результату;

- є засобом для розв'язання ключових проблем в територіальній громаді.

Висновки. Таким чином, проведене дослідження сутності та ролі стратегії соціально-економічного розвитку ОТГ в контексті зміни підходів до регіонального 
розвитку в Україні засвідчило актуальність обраної тематики. У результаті вивчення літератури виявлено необхідність формулювання авторського бачення щодо сутності терміну «стратегія ОТГ» на сучасному етапі децентралізаційних процесів у національній економічній, політичній та правовій системі.

1. Google Trends. ULR: https://trends.google.com.ua/trends/?geo=UA (дата звернення: 12.04.2021).

2. Ансофф И. Стратегическое управление. М. : Экономика, 1989. 519 с.

3. Виханский О. С. Стратегическое управление : учебное издание. М.: Гардарики, 1999. 296 с.

4. Гершун А., Горский М. Технологии сбалансированного управления. М. : Маг консалтинг, 2005. 409 c.

5. Glueck W. F., Jauch L. R. Business Policy and Strategic Managenent. New York : McGraw-Hill, 1988. $940 \mathrm{p}$

6. Гольдштейн Г. Я. Стратегические аспекты управления НИОКР : монография. Таганрог : Изд-во ТРТУ, 2000. $244 \mathrm{c}$

7. Кравченко О.В. Поняття стратегії розвитку підприємства. Вісник Сумського національного аграрного університету. 2007. № 1(22). С. 267-272.

8. Дойль П. Менеджмент: стратегия и тактика. СПб. : Питер, 1999. 560 с.

9. Ефремов В. С. Стратегическое планирование в бизнес-системах. М. : Финпресс, 2001. 240 с.

10.Карлофф Б. Деловая стратегия: концепция, содержание, символы. М. : Экономика, 1991. 236 с.

11. Крук М. Разработка корпоративных стратегий компании. ЭКО. 2001. № 6. С. 112-117.

12. Маркова В. Д., Кузнецова С. А. Стратегический менеджмент : курс лекций. М. : ИНФРА-М, 2002. $288 \mathrm{c}$.

13. Мескон М. Х., Альберт М., Хедоури Ф. Основы менеджмента. М. : Дело, 1992. 702 с.

14. Mintzderg H., Waters J. Tracking Strategy in an Enterpreneurial Firm. Academy of Management Journal. 1982. Pp. 465-499.

15. Пономаренко В. С., Пушкар О. І., Тридід О. М. Стратегічне управління розвитком підприємства: навч. посібник. Харків : ХДЕУ, 2002. 640 с.

16. Портер М. Стратегія конкуренції. К. : Основи, 1998. 390 с.

17. Томпсон А. А., Стрикленд А. Дж. Стратегический менеджмент: искусство разработки и реализации. М. : Банки и биржи, 1998. 422 с.

18. Туленков Н. Ключевая позиция стратегического менеджмента в организации. Проблемы теории и практики управления. 1997. № 4. С. 104-107.

19. Федулова Л. І., Захарова О. В. Особливості концепції стратегічного планування в сучасних умовах розвитку економіки. Проблеми науки. 2003. № 1. С. 42-46.

20. Chandler A. D. Strategy and structure; Chapters in the History of the history of the Industrial Enterprises. MIT Press, Cambridge, Mass, 1962. 463 p.

21. Берданова О., Вакуленко В. Стратегічне планування місцевого розвитку: практичний посібник; Швейцарсько-український проект «Підтримка децентралізації в Україні. DESPRO. K.: TOB «София-А». 2012. 88 с.

\section{References}

1. Google Trends, trends.google.com.ua/trends/?geo=UA Accessed 12April 2021.

2. Ansoff, Igor. Strategic management, Economy, 1989.

3. Vikhansky, Oleg. Strategic management, Gardariki, 1999.

4. Gershun, Andrey, and Mikael Gorsky. Balanced management technologies, Magician Consulting, 2005.

5. Glueck, William, and Lawrence Jauch. Business Policy and Strategic Managenent.McGraw-Hill, 1988.

6. Goldstein, Georgy. Strategic aspects of R\&D management: monograph. Publishing house of TRTU, 2000.

7. Kravchenko, O.V. "The concept of enterprise development strategy." Bulletin of Sumy National Agrarian University, no. 1(22),2007, pp. 267-272.

8. Doyle, Peter. Management: strategy and tactics. SPb., Peter, 1999.

9. Efremov, Victor. Strategic planning in business systems. Finpress, 2001.

10. Karlof, Bengt. Business strategy: concept, content, symbols. Economics, 1991.

11. Kruk, M. "Development of corporate strategies of the company.” IVF, no. 6, 2001, pp. 112-117.

12. Markova, Vera, and Svetlana Kuznetsova. Strategic management: course of lectures. Moscow, INFRAM, 2002.

13. Meskon, Michael, et al. Fundamentals of management. Case, 1992.

14. Mintzderg, H., and J. Waters. “Tracking Strategy in an Enterpreneurial Firm.” Academy of Management Journal, 1982, pp. 465-499.

15. Ponomarenko, Volodymyr, et al. Strategic management of enterprise development: textbook. manual. KSEU, 2002. 
16. Porter, Michael. Competition strategy. Basics, 1998.

17. Thompson, Arthur, and Arthur Strickland. Strategic Management: The Art of Design and Implementation. Banks and exchanges, 1998.

18. Tulenkov, N. "The key position of strategic management in the organization." Problems of theory and practice of management, no. 4, 1997, pp. 104-107.

19. Fedulova, L.I., Zakharova O.V. Peculiarities of the concept of strategic planning in modern conditions of economic development. Problems of science, no.1, 2003, pp. 42-46.

20. Chandler, Alfred. Strategy and structure; Chapters in the History of the history of the Industrial Enterprises. MIT Press, Cambridge, Mass, 1962.

21. Berdanova, Olga, and Vladimir Vakulenko. Strategic planning of local development. Practical guide.. DESPRO, 2012.

УДК 330.322

doi: 10.15330/apred.2.17.173-183

\title{
Малишівський T.В. ${ }^{1}$, Стефінін В.В. ${ }^{2}$ СИСТЕМА ІНСТРУМЕНТІВ ІНВЕСТИЦЙНОӦ ПОЛІТИКИ НА МІСЦЕВОМУ РІВНІ: ТЕОРЕТИЧНИЙ АСПЕКТ
}

\author{
1ДВНЗ «Прикарпатський національний університет \\ імені Василя Стефаника», \\ Міністерство освіти і науки України, \\ кафедра управління та бізнес-адміністрування, \\ вул. Шевченка, 57, м. Івано-Франківськ, \\ 76010, Україна, \\ тел.: +38095312 6606, \\ e-mail: taras.malyshivskyi@pnu.edu.ua, \\ ORCID: 0000-0002-9050-2308
}

${ }^{2}$ ДВНЗ «Прикарпатський національний університет імені Василя Стефаника»,

Міністерство освіти і науки України, кафедра теоретичної та прикладної економіки, вул. Шевченка, 57, м. Івано-Франківськ, 76010, Україна, тел.: +3800672992171, e-mail: volodymyr.stefinin@pnu.edu.ua, ORCID: 0000-0002-9115-0068

Анотація. Метою статті $є$ формування теоретичної бази для розробки єдиної системи інструментів інвестиційної політики на місцевому рівні для пї подальшого використання органами місцевого самоврядування та державної влади на місцях в процесі розробки та реалізації місцевої інвестиційної політики.

У процесі дослідження використано методи аналізу, систематизації, групування, абстрагування 3 метою визначення нормативних документів щодо регулювання діяльності органів місцевого самоврядування щодо залучення інвестицій, виокремлення та розгляду інструментів інвестиційної політики на місцевому рівні.

Інформаційну базу наукового дослідження склали наукові праці вітчизняних та зарубіжних вчених-економістів та законодавчо-нормативні документи 3 питань регулювання діяльності органів місцевого самоврядування.

Досліджено теоретичні основи системи інструментів інвестиційної політики саме на місцевому рівні. Це пов'язано $з$ тим, що органи місцевого самоврядування за своїми 